\title{
Creating a comprehensive research strategy for cutaneous neurofibromas
}

Jaishri O. Blakeley, MD, Pierre Wolkenstein, MD, PhD, Brigitte C. Widemann, MD, James Lee, MD, PhD, Lu Q. Le, MD, PhD, Rhonda Jackson, BS, Marigo Stathis, MS, and Sharad K. Verma, PhD

Neurology ${ }^{\circledR} 2018 ; 91$ (Suppl 1):S1-S4. doi:10.1212/WNL.0000000000005789

\section{Abstract}

\section{Objective}

Outside of procedural-based methods, there are currently no established medical treatments for cutaneous neurofibroma (cNF), which afflict up to $99 \%$ of patients with NF1. Further, adult patients often report cNF are the greatest burden of living with NF1. The Neurofibromatosis Therapeutic Acceleration Program (NTAP) launched a think tank to address core questions to facilitate development of effective therapeutics for cNF in people with NF1.

\section{Methods}

Experts (with and without explicit experience with NF1 or cNF) from multiple scientific and medical disciplines, representing the ranks of academia, industry, and government agencies, were invited to become a member of a team addressing a specific subset of questions pertinent to cNF. Teams met monthly to review published and unpublished materials, and created summaries about the material known and unknown that may influence therapeutic development for $\mathrm{cNF}$. Teams prioritized questions and organized supporting data, which was presented to the entire body of experts by each team at a research summit.

\section{Results}

Four themes were identified as being relevant to creating a comprehensive research strategy for cNF: (1) establishing definitions of $\mathrm{cNF}$, (2) determining the biology of cNF with respect to tumor initiation, progression, and maintenance, (3) outlining the factors that guide therapies development, and (4) defining core considerations for clinical trials design and optimization for cNF.

\section{Conclusion}

Considerations and key questions for each of the thematic areas were identified and provided basis for a request for applications launched by NTAP focused on cNF and are described in the accompanying articles of this supplement.

\author{
Correspondence \\ Dr. Blakeley \\ jblakel3@jhmi.edu
}

\section{RELATED ARTICLES}

Cutaneous neurofibromas:

Current clinical and

pathologic issues

Page S5

The biology of cutaneous neurofibromas: Consensus recommendations for setting research priorities

Page S14

Considerations for development of therapies for cutaneous neurofibroma

Page S21

Clinical trial design for cutaneous neurofibromas Page S31 


\section{Glossary}

$\mathrm{cNF}=$ cutaneous neurofibromas; NF1 = neurofibromatosis type 1; NTAP $=$ Neurofibromatosis Therapeutic Acceleration Program; $\mathbf{p N F}$ = plexiform neurofibroma.

Cutaneous neurofibromas ( $\mathrm{cNF}$ ) are tumors that bridge neurology and dermatology as they are in the skin and are composed of both dermal and neural tissues. These tumors primarily afflict people with neurofibromatosis type 1 (NF1). $\mathrm{NF} 1$ is an autosomal dominant neurogenetic syndrome caused by mutations on chromosome $17 \mathrm{q} 11.2$ resulting in the production of abnormal neurofibromin. ${ }^{1,2}$ The protein neurofibromin is highly expressed in the brain, spinal cord, and peripheral nervous system. ${ }^{3}$ In the absence of normal neurofibromin, the Ras-GTPase-activating protein is constitutively activated, contributing to abnormal cell proliferation. ${ }^{4}$

With an incidence of $1 / 2,500$ to $1 / 3,500$, NF 1 is among the most common single gene inherited conditions worldwide, affecting all ethnicities, races, and sexes equally. ${ }^{5}$ The clinical criteria for NF1 include: café-a-lait macules, axillary or inguinal freckling, 2 or more cNF or 1 or more plexiform neurofibroma ( $\mathrm{pNF}$ ), presence of an optic nerve glioma, 2 or more Lisch nodules, long-bone abnormalities or sphenoid wing dysplasia, or a confirmed diagnosis in a first-degree relative. ${ }^{6,7}$ Of all of these manifestations, $\mathrm{cNFs}$ are among the most common, affecting up to $99 \%$ of adults with NF $1 .^{8-11}$

A great deal is understood about NF1 and the cellular and molecular effects of the absence of neurofibromin and there is exciting development of therapies for NF1-associated tumors such as pNF and optic pathway gliomas. ${ }^{12,13}$ However, relatively little is known about cNF. This is partially because $\mathrm{cNF}$ are unlikely to cause fatal complications or severe neurologic morbidity. Although $\mathrm{cNF}$ are not predisposed to malignant transformation and are rarely associated with physical disability like other NF1-driven tumors, they are highly damaging to people with NF1 via disfigurement and dysesthesia. Specifically, in adults with NF1, "perceived disease visibility" is significantly associated with depression, psychosocial distress, quality of life impairment, and negative body experience for attractiveness/self-confidence. ${ }^{14,15}$ Patients report that cNF and their associated symptoms are one of their greatest concerns related to NF1. ${ }^{16,17}$ Hence, cNF represent a major underaddressed health concern for people with NF1. An important limitation to developing a range of effective therapies for $\mathrm{cNF}$ is a detailed understanding of the natural history, pathophysiology, and mechanisms underlying $\mathrm{cNF}$ development and maintenance.

The Neurofibromatosis Therapeutic Acceleration Program (NTAP), a research enterprise based in the Johns Hopkins School of Medicine focused on therapeutics for NF1associated peripheral nerve sheath tumors, launched a think tank to address core questions pertaining to the development of effective therapeutics for $\mathrm{CNF}$ in people with NF1. To do this, experts (with and without explicit experience with NF1 or cNF) from disciplines across neurology, biology, chemistry, dermatology, surgery, skin cancer, regenerative medicine/ tissue repair, wound healing, genetics, and immunology, representing the ranks of academia, industry, and government agencies, were invited to join 1 of 4 teams addressing a specific subset of questions pertinent to cNF. The teams addressed questions related to (1) definition of $\mathrm{cNF},(2)$ tumor initiation, progression, development, (3) therapies development, and (4) clinical trials design, optimization, and development. Teams met monthly remotely to draft core questions, review published and unpublished materials, and create summaries about the material known and unknown that may influence therapeutic development for cNF. Based on these conversations, teams prioritized questions and organized supporting data for presentation to the entire body of experts at a research summit. After these presentations, there were discussions and brainstorming sessions culminating in the teams generating the reports presented in this supplement.

\section{Defining cutaneous neurofibromas}

There is a continuum of benign peripheral nerve sheath tumors in people with NF1. Specifically, neurofibromas in NF1 range from pNF (deep lesions originating in nerve) to subcutaneous neurofibromas (lesions in the hypodermis of skin such that skin can be moved over the tumor) to cNF (currently defined as tumors limited to the skin, epidermis, and dermis, such that they move with the skin). ${ }^{18-20}$ A key limitation for advancing research for these tumors is the great variability in the definitions applied to NF1-associated peripheral lesions preventing efficient therapeutic development in these tumors. The first working group describes the multiple existing published classifications for $\mathrm{cNF}$ and discusses the clinical and pathologic features specific to $\mathrm{cNF}$ to help lay the framework for a comprehensive nosology for prospective validation.

\section{Biology of cutaneous neurofibromas}

This group defines the current knowledge about the underlying mechanistic, cellular, and genetic factors responsible for the formation of human cNF. They identify possible factors contributing to variable cNF behavior and propose a unified working model for cNF development addressing known and hypothesized aspects of the genetic, cellular, and spatial-temporal factors that may influence development of therapies for $\mathrm{cNF}$. 


\section{Development of therapies for $\mathrm{cNF}$}

Current treatments for $\mathrm{cNF}$ are limited to procedures addressing individual tumors. Experiences with such approaches are informative for establishing the current standard of care when starting the process of therapeutics development. This group identifies the current treatments and reported outcomes as well as the key factors to consider when creating a therapeutics development strategy for cNF. Specific considerations include the need for agents with favorable toxicity profiles given the likely need for chronic use and defining meaningful benefit in the setting of a complex neurogenetic syndrome.

\section{Clinical trial design and development paths}

The members of this working group review key considerations for clinical trials designed to assess biologic effect, safety and tolerability, and efficacy of therapies for cNF. They formed their assessment from analysis of ongoing natural history studies and the emerging experience with various tools for assessing $\mathrm{cNF}$ number, size, and change over time as well as the effect on patients as assessed by patient-reported outcomes. The authors specifically address the endpoints to be considered for cNF that affect trial design and potentially, regulatory review.

\section{Discussion}

The goal of these coordinated efforts is to define the core scientific areas to address in order to develop meaningful therapies for $\mathrm{cNF}$ and to inspire new investigation into these unique tumors. For example, related to these efforts, the Cutaneous Neurofibroma Subgroup of the Response Endpoints in Neurofibromatosis and Schwannomatosis (REiNS) International Collaboration launched in order to formally develop and evaluate endpoints for clinical trials focused on cNF (ccrod.cancer.gov/ confluence/display/REINS/Cutaneous+Neurofibromas). In addition, to address core scientific questions identified by the authors of this supplement, NTAP released a request for applications (n-tap.org). Through this and related efforts, the diverse scientific community that is committed to improving outcomes for people with NF1-associated peripheral nerve sheath tumors will be positioned to make meaningful advances that may affect not only people with NF1, but the broader population of patients with peripheral nerve pathology that affects skin and nerve function.

\section{Author contributions}

J. Blakeley: drafting and review of manuscript, development of recommendations. P. Wolkenstein: review of manuscript, development of recommendations. B. Widemann: review of manuscript, development of recommendations, subgroup leadership. J. Lee: review of manuscript, development of recommendations, subgroup leadership. L. Le: review of manuscript, development of recommendations, subgroup leadership. R. Jackson: review of manuscript and summit concept development. M. Stathis: review of manuscript and summit concept development. S. Verma: review and editing of manuscript, development of recommendations.

\section{Acknowledgment}

The authors thank fellow cNF summit participants Richard Anderson, Naba Bora, Isaac Brownell, Denise Casey, Sally Gottesman, Kurt Jarnagin, Pam Knight, Hon Sum Ko, Bruce Korf, Robert Lavker, Salvo LaRosa, Eric Legius, Jill Morris, Michael Parides, Scott Plotkin, Vincent M. Riccardi, Ken Rudd, and Hubert Weinberg for contributions.

\section{Study funding}

This work was supported by an agreement from The Johns Hopkins University School of Medicine and the Neurofibromatosis Therapeutic Acceleration Program (NTAP). Its contents are solely the responsibilities of the authors and do not necessarily represent the official views of The Johns Hopkins University School of Medicine.

\section{Disclosure}

J. Blakeley and P. Wolkenstein report no disclosures relevant to the manuscript. B. Widemann is funded through the Intramural Research Program of the NCI Center for Cancer Research and the opinions expressed here are her own and do not reflect the views of the NIH. J. Lee is a full-time employee of Dermavant Sciences. L. Le holds a Career Award for Medical Scientists from the Burroughs Wellcome Fund, the Thomas L. Shield, M.D. Professorship in Dermatology, and receives funding from the National Cancer Institute of the NIH. R. Jackson, M. Stathis, and S. Verma report no disclosures relevant to the manuscript. Go to Neurology.org/N for full disclosures.

Received November 1, 2017. Accepted in final form April 28, 2018.

\section{References}

1. Wallace MR, Andersen LB, Fountain JW, et al. A chromosome jump crosses a translocation breakpoint in the von Recklinghausen neurofibromatosis region. Genes Chromosomes Cancer 1990;2:271-277.

2. Li Y, O'Connell P, Breidenbach $\mathrm{HH}$, et al. Genomic organization of the neurofibromatosis 1 gene (NF1). Genomics 1995;25:9-18.

3. Daston MM, Scrable H, Nordlund M, et al. The protein product of the neurofibromatosis type 1 gene is expressed at highest abundance in neurons, Schwann cells, and oligodendrocytes. Neuron 1992;8:415-428.

4. Skuse GR, Kosciolek BA, Rowley PT. Molecular genetic analysis of tumors in von Recklinghausen neurofibromatosis: loss of heterozygosity for chromosome 17. Genes Chromosomes Cancer 1989;1:36-41.

5. Anderson JL, Gutmann DH. Neurofibromatosis type 1. Handb Clin Neurol 2015; 132:75-86.

6. Neurofibromatosis: conference statement: NIH consensus development conference statement. Arch Neurol 1988;45:575-578.

7. Huson SM, Compston DAS, Clark P, Harper PS. A genetic study of von Recklinghausen neurofibromatosis in south east Wales: 1: prevalence, fitness, mutation rate, and effect of parental transmission on severity. J Med Genet 1989;26:704-711.

8. Friedman JM. Epidemiology of neurofibromatosis type 1. Am J Med Genet 1999;89: $1-6$.

9. Lammert M, Friedman JM, Kluwe L, et al. Prevalence of neurofibromatosis 1 in German children at elementary school enrollment. Arch Dermatol 2005;141:71-74.

10. Evans DG, Howard E, Giblin C, et al. Birth incidence and prevalence of tumor-prone syndromes: estimates from a UK family genetic register service. Am J Med Genet A 2010;152A:327-332. 
11. Ferner RE, Huson SM, Thomas N, et al. Guidelines for the diagnosis and management of individuals with neurofibromatosis 1. J Med Genet 2007;44: 81-88.

12. Avery RA, Katowitz JA, Fisher MJ, et al. Orbital/periorbital plexiform neurofibromas in children with neurofibromatosis type 1: multidisciplinary recommendations for care. Ophthalmology 2017;124:123-132.

13. Dombi E, Baldwin A, Marcus LJ, et al. Activity of selumetinib in neurofibromatosis type 1-related plexiform neurofibromas. N Engl J Med 2016;375:2550-2560.

14. Page PZ, Page GP, Ecosse E, et al. Impact of neurofibromatosis 1 on quality of life: a cross-sectional study of 176 American cases. Am J Med Genet A 2006;140: 1893-1898.

15. Wolkenstein P, Zeller J, Revuz J, et al. Quality-of-life impairment in neurofibromatosis type 1: a cross-sectional study of 128 cases. Arch Dermatol 2001;137:1421-1425.
16. Draucker CB, Nutakki K, Varni JW, et al. The health-related quality of life of children, adolescents, and young adults with neurofibromatosis type 1 and their families: analysis of narratives. J Spec Pediatr Nurs 2017;22.

17. Lai JS, Jensen SE, Patel ZS, et al. Using a qualitative approach to conceptualize concerns of patients with neurofibromatosis type 1 associated plexiform neurofibromas (pNF) across the lifespan. Am J Med Genet A 2017;173:79-87.

18. Palmer C, Szudek J, Joe H, et al. Analysis of neurofibromatosis 1 (NF1) lesions by body segment. Am J Med Genet A 2004;125A:157-161.

19. Khosrotehrani K, Bastuji-Garin S, Riccardi VM, et al. Subcutaneous neurofibromas are associated with mortality in neurofibromatosis 1: a cohort study of 703 patients. Am J Med Genet A 2005;132A:49-53.

20. Peltonen S, Kallionpää RA, Peltonen J. Neurofibromatosis type 1 (NF1) gene: beyond café au lait spots and dermal neurofibromas. Exp Dermatol 2017;26:645-648. 


\section{Neurology}

\section{Creating a comprehensive research strategy for cutaneous neurofibromas Jaishri O. Blakeley, Pierre Wolkenstein, Brigitte C. Widemann, et al. Neurology 2018;91;S1-S4 \\ DOI 10.1212/WNL.0000000000005789}

\section{This information is current as of July 9, 2018}

\section{Updated Information \& Services}

References

Citations

Subspecialty Collections

Permissions \& Licensing

Reprints including high resolution figures, can be found at: http://n.neurology.org/content/91/2_Supplement_1/S1.full

This article cites 19 articles, 2 of which you can access for free at: http://n.neurology.org/content/91/2_Supplement_1/S1.full\#ref-list-1

This article has been cited by 1 HighWire-hosted articles: http://n.neurology.org/content/91/2_Supplement_1/S1.full\#\#otherarticl es

This article, along with others on similar topics, appears in the following collection(s):

Nerve tumor

http://n.neurology.org/cgi/collection/nerve_tumor

Neurofibromatosis

http://n.neurology.org/cgi/collection/neurofibromatosis

Information about reproducing this article in parts (figures,tables) or in its entirety can be found online at:

http://www.neurology.org/about/about_the_journal\#permissions

Information about ordering reprints can be found online:

http://n.neurology.org/subscribers/advertise

Neurology ${ }^{\circledR}$ is the official journal of the American Academy of Neurology. Published continuously since 1951, it is now a weekly with 48 issues per year. Copyright (C 2018 The Author(s). Published by Wolters Kluwer Health, Inc. on behalf of the American Academy of Neurology.. All rights reserved. Print ISSN: 0028-3878. Online ISSN: 1526-632X.

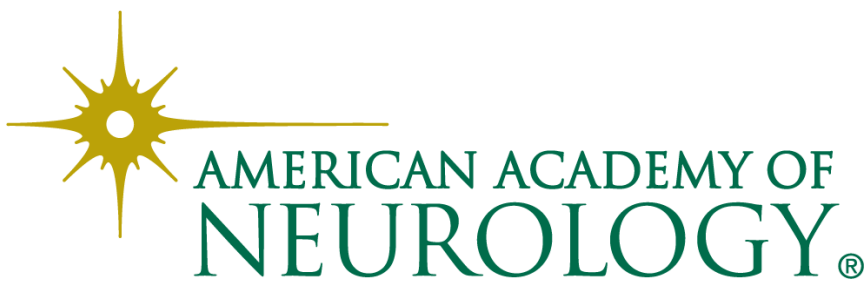

